\title{
A DESCRIPTION OF RISK FACTORS OF RECCURENT FEBRILE SEIZURE ON PEDIATRIC PATIENTS IN ABDUL WAHAB SJAHRANIE HOSPITAL IN SAMARINDA
}

\author{
Jessica Manaek Manika1, Eva Rachmi , Ahmad Wisnu Wardhana ${ }^{3}$
}

\author{
${ }^{1}$ Medical Education Study Program, School of Medicine, Mulawarman University, Indonesia \\ ${ }^{2}$ Laboratory of Anatomical Sciences, School of Medicine, Mulawarman University, Indonesia \\ ${ }^{3}$ Laboratory of Pediatrics, School of Medicine, Mulawarman University, Indonesia \\ *E-mail: jessicamanika@ymail.com
}

\begin{abstract}
Febrile seizures are the most common seizures in children. One-third of the children could develop a recurrent febrile seizure, with $75 \%$ of the recurrence occurring in the first year after the initial febrile seizure. The purpose of this study was to describe the risk factors of recurrence of febrile seizures on pediatric patients at Abdul Wahab Sjahranie Hospital in Samarinda. The research design was a descriptive study with cross sectional method. The sample of this study were children with febrile seizures whose age range were from 6 months to 5 years at Abdul Wahab Sjahranie Hospital in Samarinda from January 2017 to December 2018 who did not receive long-term prophylactic treatment for febrile seizures after the initial febrile seizure and did not experience intracranial infections, metabolic and electrolytes disorders, developmental delayed and cerebral palsy. The data were secondary data obtained from subject's medical records. The study found recurrent febrile seizures occurred on 27 samples. In this study, recurrence of febrile seizures was more common on male patients (74\%), the patients' age majority were 12 months when experiencing initial febrile seizures $(56 \%)$, as for the initial febrile seizures, they mostly experienced simple febrile seizures $(59 \%)$ and fever with 24 hour interval in initial febrile seizures $(63 \%)$. The collected data were tabulated by frequency and percentage and displayed in tables.
\end{abstract}

Keywords: recurrent febrile seizures, risk factors

\section{INTRODUCTION}

Febrile seizures are fever convulsion that often happens children. Febrile seizures are reported in 1 out of every 25 children in the general population, at least once during their childhood ${ }^{1}$. In general , one out of three children who experienced febrile seizures are at risk for having a recurrence by $75 \%$ which might occurr within 1 year after the initial febrile seizure ${ }^{2}$. Pavlidou \& Panteliadis reported that recurrence of febrile seizures increased the risk of epilepsy in the future by 9-7 times ${ }^{3}$.

There are several factors related to the recurrence of febrile seizures, such as family history of febrile seizures, kids whose age were less than 12 months, body temperature less than $39 \mathrm{C}$ during seizures, and short intervals between the onset of fever and the occurrence of seizures ${ }^{4}$. In addition to these four factors, the presence of gender factors, family history of epilepsy, and complex febrile seizures in the initial febrile seizure are also predictive factors for recurrence of febrile seizures ${ }^{5}$. Children who have all of these risk factors are more likely to experience a recurrence of febrile seizures as much as $80 \%$ and those without those risk factors are $10-15 \%$ might experience recurrence. The likelihood of recurrence of febrile seizures is higher in the first year ${ }^{6}$. 
Researchers considered that the recurrence of febrile seizures could increase the risk of epilepsy, so it is necessary to find out the factors that might influence the recurrence of febrile seizures. This has attracted the attention of researchers to examine the risk factors for recurrence of febrile seizures in pediatric patients at Abdul Wahab Sjahranie Hospital in Samarinda.

\section{MATERIAL AND METHOD}

This descriptive study applied cross sectional method. The sample of this study were all pediatric patients with a diagnosis of recurrent febrile seizures with more than one fever episode at Abdul Wahab Sjahranie Hospital in Samarinda from January 2017 - December 2018. The data were secondary data obtained from patients' medical records. This research used purposive sampling. The inclusion criteria in this study were age between 6 months - 5 years. Exclusion criteria were incomplete medical record file, such as patient who got prophylactic treatment for long-term febrile seizures in previous febrile seizures or having intracranial infections, metabolic and electrolyte disorders, developmental delayed and cerebral palsy. The variables of this study were recurrence of febrile seizures, gender, age at the initial febrile seizure, type of initial febrile seizure and fever interval at the initial febrile seizure experienced by the patient. This research was conducted at the Medical Record Installation of Abdul Wahab Sjahranie Hospital in Samarinda from July to August 2019. Data were tabulated by using the Microsoft Office Excel 2016. Data presentation was displayed in tabular and narrative form.

\section{RESULTS AND DISCUSSION}

From the medical records of patients with febrile seizures at Abdul Wahab Sjahranie in Samarinda from January 2017 - December 2018, the research found 27 patients who experienced a recurrence of seizures fever. The result on patients is presented in the following table (Table 1).

Table 1. Frequency Distribution of Risk Factor of Recurrent Febrile Seizures

\begin{tabular}{lcc}
\hline Risk Factors & $\begin{array}{c}\text { Total } \\
(\mathrm{f}=27)\end{array}$ & $\begin{array}{c}\text { Percentage } \\
(100 \%)\end{array}$ \\
\hline Gender & 20 & 74 \\
Male & 7 & 26 \\
Female & & \\
Age when experiencing initial febrile seizures & 15 & 56 \\
12 months & 12 & 44 \\
$>12$ months & & \\
Initial febrile seizure & 11 & 41 \\
Complex & 16 & 59 \\
Simple & & \\
Fever interval at initial febrile seizure & 17 & 63 \\
24 hours & 10 & 37 \\
$>24$ hours &
\end{tabular}

This study found that recurrence of febrile seizures was more common in male patients, gender ratio of male to female was 1.5:1. These result is in line with previous studies that found out the gender of patients who experienced recurrence of febrile seizures were mostly male $5,7,8,9,14$. Different results were found in other studies which showed the gender of recurrence of febrile seizures were mostly female ${ }^{4,10}$. Hence, it can be concluded that gender is not a risk factor for recurrence of febrile seizures ${ }^{16}$. 
Based on the age of the patients when they experienced febrile seizures for the first time, the majority were in the age group 12 months, as many as 15 patients (56\%). The age of the occurrence of febrile seizures was associated with a period of brain development. At the age of less than 12 months, the brain is still immature, excitatory receptors are more dominant than receptor inhibitors ${ }^{11}$. Children who have first febrile seizures at the age of 12 months or less have a $65 \%$ chance of having recurrence of febrile seizures, on the other hand, those who are over 12 months have $35 \%$ chance of having recurrent febrile seizure ${ }^{12}$. The results of this study are in line with previous studies which stated that the occurrence of febrile seizures recurred frequently in patients in the age group $<12$ months ${ }^{13,9}, 14$. Different results were found in a similar study which showed that recurrence of febrile seizures occurred in the age group $>12$ months $^{5,8}$.

This study found that recurrence of febrile seizures was more common in the type of simple febrile seizure in the initial febrile seizure experienced by 16 patients $(59 \%)$. These result is in accordance with previous studies which showed the most common type of febrile seizures experienced by patients with recurrence of febrile seizures was simple febrile seizures ${ }^{4,17}$. A meta-analysis study reported the percentage of simple febrile seizures in the first febrile seizure was as many as $69.3 \%{ }^{15}$. Different results were stated in other studies that found that complex febrile seizures were experienced by patients during their initial febrile seizures $9,10,14$. The complex febrile seizures in the initial febrile seizure as a risk factor for recurrence of febrile seizures is still being debated until now ${ }^{18}$. The type of complex febrile seizures in the initial febrile seizure is considered an inconsistent risk factor for the recurrence of febrile seizures ${ }^{19}$.

Based on the fever interval in the initial febrile seizure that was experienced by patients with recurrence of the first febrile seizure before the occurrence of febrile seizures was 24 hours. The difference in the fever interval for each child was due to the seizure threshold for each child was different ${ }^{20}$. This result is in line with previous studies which found that fever intervals of patients who experienced recurrence of febrile seizures were mostly 24 hours ${ }^{10,14}$. Other studies have found febrile seizures recurrence on patients who experienced fever similar intervals between 24 hours or $>24$ hours 10 .

\section{CONCLUSION}

Based on the results of reccurent febrile seizure on pediatric patients in Abdul Wahab Sjahranie Hospital in Samarinda, the conclusion is as follows:

1. The recurrence of febrile seizures were more often happened in male patients with a ratio of male and female at $1.5: 1$.

2. Age group of kids with recurrent febrile seizures who experienced febrile seizures is 12 months.

3. Type of initial febrile seizures that occurred mostly was simple febrile seizure.

4. The fever intervals in the initial febrile seizure in patients who experience recurrence of febrile seizures were 24 hours.

\section{REFERENCES}

1. Gunawan, W., Kari, K., \& Soetjiningsih, S. Knowledge, Attitude, and Practices of Parents with Children of First Time and Recurrent Febrile Seizures. Paediatrica Indonesiana, 48(4), $193-$ 198 (2008). 
2. Berg, A. T., Shinnar, S., Hauser, A., Alemany, M., Shapiro, E. D., Salomon, M. E., \& Crain, E. F. A Prospective Study of Recurrent Febrile Seizures. The New England Journal of Medicine, 327(16), 1122-7 (1992).

3. Pavlidou, E., \& Panteliadis, C. Prognostic factors for subsequent epilepsy in children with febrile seizures. Wiley Periodicals, Inc., 54(12), 2101-2107 (2013).

4. Yunita, V. E., Afdal, A., \& Syarif, I. Gambaran Faktor yang Berhubungan dengan Timbulnya Kejang Demam Berulang pada Pasien yang Berobat di Poliklinik Anak RS. DR. M. Djamil Padang Periode Januari 2010 - Desember 2012. Jurnal Kesehatan Andalas, 5(3), 705-709 (2016).

5. Marudur, P. T., Herini, E. S., \& Satria, C. D. Predictive Factors for Recurrent Febrile Seizures in Children. Paediatrica Indonesiana, 53(6), 317-323 (2012).

6. Ismael, S., Pusponegoro, H. D., Widodo, D. P., Mangunatmadja, I., \& Handryastuti, S. Rekomendasi Penatalaksanaan Kejang Demam. Unit Kerja Koordinasi Neurologi Ikatan Dokter Anak Indonesia (hal. 1-16). Jakarta: Badan Penerbit Ikatan Dokter Anak Indonesia (2016).

7. Ridha, N. R., Nara, P., Hadia, A., \& Dasril, D. Identification of Risk Factors for Recurrent Febrile Convulsion. Pediatrica Indonesiana, 49(2), 87-90 (2009).

8. Gunawan, P. I., \& Saharso, D. Faktor Risiko Kejang Demam Berulang pada Anak. Media Medika Indonesiana, 46(2), 75-79 (2012).

9. Jamal, M., \& Ahmed, W. To Identify The Factors Affecting The Risk of Recurrent Febrile Seizures in Saudi Children. Pak Armed Forces Med J, 65(4), 458-463 (2015).

10. Rane, M., Nistane, R., Barabde, P., \& Jahagirdar, S. Risk Factors For Recurrence of Febrile Seizures in Children Aged Between 6 Months to 5 Years of Age Admitted to DR. Punjabro Deshmukh Medical College, Amravati. Journal of Evolutionof Medical and Dental Sciences, 4(88), 15340-15344 (2015).

11. Dewanti, A., Widjaja, J. A., Tjandrajani, A., \& Burhany, A. A. Kejang Demam dan Faktor yang Mempengaruhi Rekurensi. Sari Pediatri, 14(1), 57-61 (2012).

12. Fishman, M. A. (2014). Kejang Demam. Dalam A. M. Rudolph, J. I. Hoffman, \& C. D. Rudolph, Buku Ajar Pediatri Rudolph (hal. 2160-1). Jakarta: EGC.

13. Alwan, Y. F., \& Hussein, H. J. Risk Factors for Recurrent Febrile Convulsions in Children. Al Kindy College Medical Journal, 9(2), 14-16 (2013).

14. Indriani, A., Risan, N. A., \& Nurhayati, T. Five Years Study of Recurrent Febrile Seizure Risk Factors. $A M J, 4(2), 282-285$ (2017).

15. Veisani, Y., Delpisheh, A., \& Sayehmiri, K. Predictors of Recurrent Febrile Seizure in Iranian Children. Zahedan Journal of Research in Medical Sciences, 15(9), 1-5 (2013).

16. Shinnar S. (2012). Febrile Seizures. Dalam Swaiman K. F., Ashwal S., Ferriero D. M., Schor N. F., Swaiman's Pediatric Neurology, Principles and Practice Ed. 5 (hal. 790-7). Edinburgh: Elsevier Health Sciences.

17. Vebriasa, A., Herini, E. S., \& Rina, T. Hubungan antara Riwayat Kejang pada Keluarga dengan Tipe Kejang Demam dan Usia saat Kejang Demam Pertama. Sari Pediatri, 15(3), 137-140 (2013).

18. Hirtz, D. G. Febrile Seizures. Pediatrics in Review, 18(5), 5-9 (1997).

19. Daoud, A. Febrile Convulsion: Review and Update. J Pediatr Neuro, 2(1), 9-14 (2004).

20. Fuadi, F., Bahtera, T., \& Wijayahad, N. Faktor Risiko Bangkitan Kejang Demam pada Anak. Sari Pediatri, 12(3), 142-149 (2010). 